\title{
The International Refugee Match:
}

A system that respects refugees' preferences and the priorities of states

\begin{abstract}
There is an urgent need to overcome the political deadlock preventing states substantively participating in burden-sharing in the international refugee regime, and, in particular, finding solutions to the European refugee crisis. We propose a centralised clearinghouse - a 'two-sided matching system' - to match refugees with states. Drawing on the success of matching in domains, such as education and healthcare, we outline the principles underlying matching system design, and illustrate in general terms how they could be applied to refugee protection. This matching system respects the priorities of states and gives agency to refugees. Matching systems can operate independently or alongside other burden-sharing mechanisms, such as tradable refugee quotas (as suggested by Fernández-Huertas Moraga and Rapoport). We then move to consider two specific empirical cases: international resettlement and the European migrant crisis.
\end{abstract}

Keywords: refugees, forced migration, market design, matching, resettlement, Europe, EU, burden-sharing.

Words: 12,484 .

\section{INTRODUCTION}

As the number of refugees reaches its highest level globally since the Second World War, and Europe faces the largest mass influx of refugees in its history ${ }^{1}$, the international refugee regime is looking increasingly shaky. Faced with 200,000 refugees fleeing the ongoing slow-motion

\footnotetext{
${ }^{1}$ C Alfred, 'What History Can Teach Us About The Worst Refugee Crisis Since WWII'. The Huffington Post, September 12. http://www.huffingtonpost.com/entry/alexander-betts-refugeeswwii_55f30f7ce4b077ca094edaec.
} 
collapse of Syria and the rise of so-called Islamic State, the European Union response has been inconsistent, poorly coordinated, and (to date) inadequate to the scale of the problem. In this context, there have been repeated calls for the revision or outright abolition of the Dublin III Regulation, ${ }^{2}$ particularly its requirement that the first country in the EU that asylum seekers enter be responsible for processing their claim, ${ }^{3}$ and it looks likely to be scrapped. ${ }^{4}$ As Costanza Hermanin, a senior analyst in migration and equality for the Open Society Foundation has noted, 'after 25 years, it doesn't work anymore.' Across the world, the rise of far-right antimigrant political parties and security rhetoric have led to governments' implementing ever more restrictive asylum and immigration policies. ${ }^{5}$

At the time of writing, there are renewed calls to make the largely aspirational Common European Asylum System (CEAS) a reality. ${ }^{6}$ As Alexander Betts recently noted in the New York Times, 'Europe needs a comprehensive global refugee policy'. ${ }^{7}$ This is, therefore, a useful juncture to consider innovative suggestions as to how the mechanisms which might underpin such a policy could be made fairer, safer, and more effective. In this paper, we consider how insights from over thirty years of work in economics, operations research, and computer science on matching theory and market design can provide guidance on how to implement a desirable refugee policy. First, we briefly review the academic literature and recent applications

\footnotetext{
${ }^{2}$ The Dublin III Regulation is the European Law 'establishing the criteria and mechanisms for determining the Member State responsible for examining an asylum application lodged in one of the Member States by a thirdcountry national.'

${ }^{3}$ C Costello, , and M-G Guiffré. “"Tragedy” and Responsibility in the Mediterranean'. Open Democracy. April 27, 2015. https://www.opendemocracy.net/can-europe-make-it/mariagiulia-giuffr\%C3\%A9-cathryncostello/crocodile-tears-tragedy-and-responsibility-i; K Koser, 'Time to Reform the International Refugee Regime'. OUPblog. 2015. http://blog.oup.com/2015/09/international-refugee-regime-reform/.

${ }^{4}$ George Parker and Duncan Robinson, 'Cameron Opposes Change to EU "Dublin" Rule on Hosting of Refugees', Financial Times, 20 January 2016.

${ }^{5}$ B S Chimni,. 'The Global Refugee Problem in the 21st Century and the Emerging Seucity Paradigm: A Disturbing Trend'. In Legal Visions of the 21st Century: Essays in Honour of Judge Christopher Weeramantry, edited by A Anghie and G Sturgess. Martinus Nijhoff Publishers, 1998. J Huysmans, The Politics of Insecurity: Fear, Migration and Asylum in the EU. Routledge, 2006.

${ }^{6}$ V Chetail, P De Bruycker, and F Maiani, eds., Reforming the Common Asylum System: The New European Refugee Law (Leiden/Boston: Brill/Nijhoff, 2016); V Chetail, 'Looking Beyond the Rhetoric of the Refugee Crisis: The Failed Reform of the Common European Asylum System', European Journal of Human Rights 5 (2016): 584-601; M den Heijer, J Rijpma, and T Spijkerboar, 'Coercion, Prohibition, and Great Expectations: The Continuing Failure of the Common European Asylum System', Common Market Law Review 53, no. 3 (2016): 607-42; C Bauloz et al., eds., Seeking Asylum in the European Union: Selected Protection Issues Raised by the Second Phase of the Common European Asylum System (Leiden: Brill/Nijhoff, 2015); S Velluti, Reforming the Common European Aslyum System - Legislative Developments and Judicial Activism of the European Courts (Springer, 2014); S Peers, 'The Second Phase of the Common European Asylum System - A Brave New World or Lipstick on a Pig?', Statewatch Analysis, 2013.

${ }^{7}$ S Erlanger, and A Smale. 'Europe's Halting Response to Migrant Crisis Draws Criticism as Toll Mounts'. The New York Times, August 28, 2015. https://www.nytimes.com/2015/08/29/world/europe/europe-migrant-refugeecrisis.html.
} 
of matching in different real world contexts. Second, we explain in general terms how matching could be productively applied to help states cooperate in refugee protection and burden-sharing, and how it makes that cooperation more likely. Then we consider two specific contexts: the global refugee resettlement mechanism and the current European refugee crisis. Finally, we outline and respond to some potential objections.

There are effectively two major problems we believe matching can address. First, the processes whereby refugees do or not do not get protected by particular countries are often arbitrary, unfair, unsafe, and ineffective. Some countries, such as Sweden and Germany, are considerably more assiduous than others in welcoming refugees, but which country a refugee ends up in is largely left to chance. Refugees play an extremely dangerous lottery when they select which country to apply for asylum in. In the case of global resettlement, refugees have little to no freedom over where in the world they will be resettled to. In the case of Europe, refugees must gamble by applying for asylum in only one European country. In both cases, this denudes refugees of agency and puts them through processes which are wracked with arbitrariness, 'calculated kindness', 8 and bad faith. Second, from the perspective of states, refugee flows are chaotic, unpredictable, and widely regarded as socially disruptive and destabilising. Inter alia, this foments anti-migrant politics, undermines sympathy with refugee groups, and limits the effectiveness of refugee reception programmes. States therefore seek to restrict and regulate migration flows, often in ways incompatible with their international legal obligations, to say nothing of the rights of refugees themselves. To the extent that states try to meet rapidly changing international movements of people with inflexible ad hoc arrangements, refugee protection becomes more expensive, wasteful, ineffective, and - for those reasons less likely to happen at all.

The two aims of expanding the agency of refugees and enabling states to control and manage migration are usually seen as in tension. It is our belief that both can be met more successfully through the use of a matching system - the Refugee Match - which uses no monetary transfers, better respects the freedom and choices of refugees, and serves the core interests of states in regulating their borders.

The proposed mechanism would require a group of states to coordinate minimally with each other insofar as they would have to opt into the Refugee Match, but it need not force states to abandon any of their current agendas, be they liberal, or restrictive (for example, it is

\footnotetext{
${ }^{8}$ G Loescher, and J A Scanlan. 1998. Calculated Kindness. Simon and Schuster.
} 
compatible with minimum or maximum refugee quotas, or neither). In consequence, a marketlike system of the form we propose would give states additional incentives to engage in cooperative behaviour, increase quotas, and therefore promote interstate arrangements on burden-sharing, such as the CEAS.

Concretely, what we propose is a system that matches states to refugees and refugees to states. Obviously, it would be tremendously beneficial if every state participated in resettlement with such generosity that any refugee could have a literally unconstrained choice as to where they go. But such a world bears no resemblance to reality. However, somewhat less ambitiously and more realistically, a subset of countries could undertake to resettle a given population of refugees, as some states do now, and have historically. This could also be used in the instance of some other category of protection seekers, such as that outlined in the 2001 Temporary Protection. Participating states and refugees would give their preferences - over which refugees they most wish to host or which state they most wish to be protected in - to a centralised clearinghouse which matches them according to those preferences. Refugees, in principle, could submit their preferences from anywhere.

The outcome of this mechanism satisfies a host of desirable properties. This system involves no money changing hands between states, or between states and refugees (similar to how a parent's choice of their children's primary school operates today), works within quotas or under other distributional constraints, can be made to guarantee that all refugees within the system are hosted somewhere, can ensure that no refugee can be made better off (given their stated preferences) without making at least one other refugee worse off, and can be made 'safe' for states and refugees to honestly reveal their true preferences. Such a system could operate either in situations where a mass influx must be assisted rapidly, or with systems which operate as a matter of routine (e.g. global resettlement). This system would only allocate the refugees to countries that are participating in the Refugee Match, and therefore would have no effect on the right of refugees to apply for asylum by the conventional route of making to a given state's territory, much as resettlement currently does not.

The use of economic theory in refugee protection is not new. Most prominently, Peter Schuck proposed a system in which states would be permitted to purchase and sell quota compliance obligations. ${ }^{9}$ It is important to recognise how different our proposal is. The Refugee Match merely sets out a way to find the optimal allocation of a given population refugees

\footnotetext{
${ }^{9}$ P H Schuck, 'Refugee Burden-Sharing: A Modest Proposal', Yale J. Int'l L. 22, 1997: 243.
} 
amongst a given population of states, given their preferences and given states' quotas. No buying or selling of quotas is involved. We agree with those who regard the buying and selling of refugees in such a manner as morally repugnant, and likely to lead to worse protection in practical terms, ${ }^{10}$ although in principle our proposal is compatible with this system, or any other burden-sharing agreement. It would work with Schuck's tradable quotas as much as it would with the planned economy of Hathaway and Neve, ${ }^{11}$ or the system of humanitarian visas bestowed at consular outposts outside the European Union, ${ }^{12}$ recently advocated by Alexander Betts. ${ }^{13}$ We are agnostic as to how burdens should be optimally shared, but we do argue that any burden-sharing agreement which then uses a matching system is better for refugees and more likely to be assented to by states.

The idea of quota-trading has been recently revived by economists, ${ }^{14}$ endorsed by some political theorists, ${ }^{15}$ and criticised by others. ${ }^{16}$ Fernández-Huertas Moraga and Rapoport are the first to propose and mathematically develop applying matching models to the allocation of refugees across destinations, in combination with a quota-trading scheme in order to overcome the incentives of states to makes themselves undesirable resettlement destinations. The main applications they consider are refugee resettlement in general and resettlement/relocation within the EU. In their papers, they use matching mechanisms to take into account the preferences of refugees over destinations, and possibly the priorities of destination countries over refugee types, as part of a broader allocation scheme where countries receive quotas that can be traded with others.

We would agree with Fernández-Huertas Moraga and Rapoport that the only way of making a tradeable quota system palatable is if it is implemented with a matching system, but

\footnotetext{
${ }^{10}$ D Anker, J Fitzpatrick, and A Shacknove, 'Crisis and Cure: A Reply to Hathaway/Neve and Schuck', Harvard Human Rights Journal 11, 1998: 295.

${ }^{11}$ J C Hathaway and R A Neve, 'Making International Refugee Law Relevant Again: A Proposal for Collectivized and Solution-Oriented Protection', Harv. Hum. Rts. J. 10, 199): 115.

${ }^{12}$ U I Jensen, 'Humanitarian Visas: Option or Obligation?', Study for the LIBE Committee, Directorate-General for Internal Policies, European Parliament, 2014.

${ }^{13}$ Alexander Betts, 'Let Refugees Fly to Europe', New York Times, 24 September 2015, Online Edition edition, http://www.nytimes.com/2015/09/25/opinion/let-refugees-fly-to-europe.html?nytmobile=0.

14 J Fernández-Huertas Moraga, and H Rapoport. 'Tradable Refugee-Admission Quotas and EU Asylum Policy'. CESifo Economic Studies 61, no. 3-4, 2015: 638-72. doi:10.1093/cesifo/ifu037. 'Tradable Immigration Quotas'. Journal of Public Economics 115, July 2014: 94-108. doi:10.1016/j.jpubeco.2014.04.002. 'Tradable Refugee-Admission Quotas (TRAQs), the Syrian Crisis and the New European Agenda on Migration'. IZA Journal of European Labor Studies 4, no. 1, 2015: 23.

${ }^{15}$ J Kuosmanen, 'What (If Anything) Is Wrong with Trading Refugee Quotas?', Res Publica 19, no. 2,25 September 2012: 103-19, doi:10.1007/s11158-012-9198-y.

${ }^{16}$ M J Gibney, 'Refugees and Justice between States', European Journal of Political Theory, 25 May 2015, 1474885115585325, doi:10.1177/1474885115585325.
} 
in this paper we seek to explore the value and the design details of a matching system in itself, with or without tradeable quotas. In their work, they work through the operation of matching mathematically for an audience of economists. The present paper is not purporting to add to the stock of knowledge in mathematical economics. Rather, it develops the concept framed for an audience in refugee studies, adds considerable institution detail, fine-grained operational concerns, and evaluates the proposal with reference to common worries and normative frameworks within the field. Nevertheless, we expect that many insights in this paper would be useful for building better mathematical models of refugee resettlement schemes.

In practice, the absence of a formalised system, which enables states to trade quotas in refugees, has not prevented them from engaging in actions with precisely the same effects. For example, many EU states are currently transferring resources to protect Syrian refugees in Turkey in the hope this will diminish the numbers attempting the onward journey to continental Europe. ${ }^{17}$ This is, in practical terms, no different from paying Turkey in order to transfer protection obligations from European states to Turkey, except insofar as it is less transparent than a formalised system of tradable quotas.

In the rest of this paper, we focus explicitly on the design of the Refugee Match under the institutional constraints of today. For example, we take states' interests, and limited willingness to host refugees as given. We assume only minimal changes to international refugee law are possible. We will argue that the Refugee Match can play an important complementary role within current international refugee assistance frameworks.

\section{MATCHING THEORY}

Two-sided matching theory is a mathematical framework for allocating of resources where both parties to the transaction need to agree to the match in order for a match to take place. One popular (among matching theorists) example of 'one-to-one' two-sided matching is (nonpolygamous, consensual, heterosexual) marriage. In this case, the two 'sides' are men and women. A 'match' here is a marriage. No man can get married without the agreement of a woman, and vice versa. Men and women have preferences over partners on the other side. For example, Arabella may prefer Boris to Ciarán, whereas Davina may prefer Ciarán to Boris.

\footnotetext{
${ }^{17}$ See, for example, the EU-Turkey joint statement of $18^{\text {th }}$ March 2016.
} 
Boris and Ciarán would also have preferences concerning Arabella and Davina. ${ }^{18}$ Economists often describe this as a 'matching market' in the sense only that it is a scenario in which agents make choices seeking to maximise their preferences within given constraints - there need not be money involved, let alone prices. Gale and Shapley ${ }^{19}$ showed that any such one-to-one twosided matching market (such as renting apartments or getting taxi rides) has a stable outcome and described an algorithm (which can be implemented quickly on a computer) that finds it. 'Stable' here denotes a situation where, first, no individual prefers to be alone to the match that they have ended up with, and second, no pair would like to drop their respective partners and rematch with each other.

One well studied and carefully designed 'many-to-one' matching system is the National Resident Matching Program (NRMP) in the United States, which allocates junior medical interns to hospitals. ${ }^{20}$ The NRMP has, in fact, been using the Gale-Shapley algorithm to allocate since the 1950s. Besides producing a stable outcome, the ongoing success of the NRMP relies on two further important properties of this algorithm. ${ }^{21}$ First, there is an outcome in this manyto-one matching system is Pareto-efficient, meaning that nobody can be made any better off without making any other party worse off. Work in refugee studies has rightfully raised concerns over the loaded and misleading ways in which the language of 'efficiency' is deployed in political discourse. ${ }^{22}$ Alexander Betts has argued, however, that there are legitimate uses of the language of efficiency in refugee studies. ${ }^{23}$ When we refer to efficiency in this paper, we simply mean Pareto efficiency (or 'allocative efficiency', in Betts' language). ${ }^{24}$ Second, reporting your ranking to a system that produces a stable outcome is 'safe' for one side of the match, meaning that that one side of the match has no incentive to misrepresent their preferences to the clearinghouse (e.g. their ranking of hospitals, universities, marriage partners, or whatever) in order to game the system (this is sometimes called 'incentive-compatibility',

\footnotetext{
18 They may also prefer to be single to marrying a particular partner.

${ }^{19}$ D Gale, and L S Shapley, 'College Admissions and the Stability of Marriage'. American Mathematical Monthly, 9-15, 1962.

${ }^{20}$ A E Roth, 'The Evolution of the Labor Market for Medical Interns and Residents: A Case Study in Game Theory'. The Journal of Political Economy, 1984, 991-1016.

${ }^{21}$ A E Roth, 'A Natural Experiment in the Organization of Entry-Level Labor Markets: Regional Markets for New Physicians and Surgeons in the United Kingdom'. The American Economic Review, 1991, 415-440.

${ }^{22}$ M Gibney and R Hansen, 'Asylum Policy in the West: Past Trends, Future Possibilities', in Poverty, International Migration and Asylum, ed. G J Borjas and J Crisp, Palgrave Macmillan, 2005.

${ }^{23}$ Alexander Betts, 'What Does "Efficiency" Mean in the Context of the Global Refugee Regime?', The British Journal of Politics \& International Relations 8, no. 2, 2006: 148-173.

${ }^{24}$ There is a more involved discussion of what efficiency can mean in the context of a proposed matching system for refugee below.
} 
or 'strategy-proofness'). Moreover, Roth showed ${ }^{25}$ that if the doctors do the proposing, then they have no incentive to misrepresent their preferences and game the system because the GaleShapley procedure selects the outcome that is most preferred for every doctor, of all stable allocations. ${ }^{26}$ For this reason, Roth suggested that the NRMP should switch from a hospitalproposing Gale-Shapley algorithm to a doctor-proposing one, in order to produce a system where doctors felt safe revealing their real preferences about which hospitals they wished to go to, and ended up with the best possible stable outcome for the doctors (rather than the hospitals).

Stability has been key to designs of many matching systems. Roth ${ }^{27}$ examined medical job application procedures in the United Kingdom. At the time, the UK operated with many different systems across different parts of the country, some of which used methods, which produced stable outcomes, some of which did not. He found that in almost all instances whenever a matching mechanism is unstable in the technical sense it is also unstable in the vernacular: those systems unravelled as doctors and hospitals sought to 're-match' outside of the system (i.e. under the table).

Since the late 1990s, there has been an explosion in the number of applications of matching systems. One famous application of two-sided matching systems has been the allocation of students to public schools in Boston and New York. ${ }^{28}$ What Abdulkadiroğlu and Sönmez showed is that the procedure used at the time by the Boston school authority was neither stable nor strategy-proof. This meant that parents had incentives to try and game the system, and richer parents tended to be disproportionately good at doing so. Not only was there "rematching' outside the system (as students sought places in schools that they were not matched to), but the Boston school authorities also had no reliable information about which schools were genuinely preferred by students and their parents. The designers of the match managed to convince the school authorities to change their mechanism to Gale-Shapley, which they have

\footnotetext{
${ }^{25}$ A E Roth, 'On the Allocation of Residents to Rural Hospitals: A General Property of Two-Sided Matching Markets', Econometrica 54, no. 2, 1986: 425-27.

${ }^{26}$ Hospitals may be able to manipulate the Gale-Shapley algorithm even if they propose. In one-to-one matching whichever side proposes in a Gale-Shapley algorithm can safely reveal their true preferences.

${ }^{27}$ A E Roth, 'A Natural Experiment in the Organization of Entry-Level Labor Markets: Regional Markets for New Physicians and Surgeons in the United Kingdom'. The American Economic Review, 1991, 415-440.

${ }^{28}$ A Abdulkadiroğlu, and T Sönmez. 'School Choice: A Mechanism Design Approach'. The American Economic Review 93 (3), 2003: 729-747. A Abdulkadiroğlu, P A Pathak, and A E Roth. 'The New York City High School Match'. American Economic Review 95 (2), 2005: 364-367.
} 
used ever since. Other applications of two-sided matching have included the match of cadets to branches of the US Army ${ }^{29}$ and admission of students to universities in Germany. ${ }^{30}$

It is also worth noting that matching does not necessarily need to be two-sided. Agents may not be neatly divided into sides, but may still wish to match (as when students look for housemates). Famous applications of one-sided matching systems include pairwise exchange of kidneys ${ }^{31}$ and the allocation of public housing. ${ }^{32}$ Most importantly, most applications of matching systems, including the one we will describe in this paper, do not involve the exchange of money. Many systems, such as a market for organs, may be justifiably considered (what Roth $^{33}$ calls) 'repugnant' if money were introduced in transactions. ${ }^{34}$

In all these cases, matching systems were designed to suit the particular constraints of the problem in question. Economists are usually guided by attempting to design a matching system that produces outcomes that are stable, efficient, and strategy-proof, but what that means in particular cases changes. The point of designing the system is to ensure that students are matched to the schools they wish to go to, or tenants to the houses they actually wish to live in, or doctors to the hospitals they wish to work at. If the systems described above were not designed, but instead decentralised, they would probably be unable to overcome the informational and temporal frictions that plague them. The consequences of this are students ending up in schools they do not wish to attend, doctors mismatched to hospitals, and patients being unable to find the kidney that could save their life. ${ }^{35}$

\footnotetext{
${ }^{29}$ T Sönmez, and T B Switzer. 'Matching With (Branch-of-Choice) Contracts at the United States Military Academy'. Econometrica 81 (2), 2013: 451-488.

${ }^{30}$ A Westkamp, 'An Analysis of the German University Admissions System'. Economic Theory 53 (3), 2013 : 561-589.

${ }^{31}$ A E Roth, T Sönmez, and M U Unver. 2004. 'Kidney Exchange'. Quarterly Journal of Economics 119 (2), 2004: 457-88.

${ }^{32}$ A Abdulkadiroğlu, Atila, and T Sönmez, 'House Allocation with Existing Tenants'. Journal of Economic Theory 88 (2), 1999: 233-260.

${ }^{33}$ A E Roth, 'Repugnance as a Constraint on Markets'. The Journal of Economic Perspectives 21 (3): $2,2007$.

${ }^{34}$ A magisterial summary of the successes of matching systems and market design is A E Roth, Who Gets What - and Why: The Hidden World of Matchmaking and Market Design, Harper Collins Publ. UK, 2015.

${ }^{35}$ One example of a system which has repeatedly failed is the matching of clerks to judges in the US judiciary Christopher Avery et al., 'The New Market for Federal Judicial Law Clerks', The University of Chicago Law Review, 2007, 447-486.. The reason for the failure is the resistance of judges to playing by any centralised rules of the game, even though many judges recognise that the current system is broken. For example, judges are incentivised to give early 'exploding' offers (i.e. which expire very quickly if they are not accepted) to clerks, thereby often ending up hiring clerks they do not want, and clerks working for judges they do not particularly want to work for.
} 


\section{A MANY-TO-ONE MATCH FOR REFUGEES: WHY}

The situation of refugees is already a matching market. It just happens to be a 'decentralised' one: there is no clearinghouse, but states and refugees nonetheless match. In order to become a refugee in a particular country, they must be accepted by that country, and voluntarily choose to live there. A refugee can only avail themselves of the protection of one country, but one country can take many refugees, making this a many-to-one matching market, similar to those of the NRMP or college admissions.

In most general terms, a centralised matching system for refugees would allow refugees to apply for protection in several countries and allow countries to compete to protect different refugees. In one potential system, refugees could make one claim for asylum to a single centralised body, simultaneously specifying where, if successful, they would wish to be relocated. A different system would be one where states have identified in advance a population to be resettled (either through a group determination of status, or some other special dispensation). The match would then match refugees to countries. States come to the clearinghouse with a quota of refugees they are willing to accept (we discuss minimum and maximum quotas in the next section) and a ranking of the refugees. They are then matched.

Centralising this system would require harmonising eligibility procedures and refugee determination of status decisions. This is an important precondition for the system to work well. In any such system, it would need to be a certainty that, once the state and the refugee have been matched, this match will actually happen (which is to say, that individual will be granted refugee status in whichever country they have been matched to). States are sometimes thought to be 'jealous' guardians of their sovereignty, and unwilling to cede it in any circumstances. However, it has been a matter of broad consensus in International Relations across many disciplinary divides since at least the 1980s that there is a wide set of circumstances in which states can and do cooperate and surrender sovereignty to interstate regulatory frameworks. ${ }^{36}$ There is much disagreement on precisely why states cooperate, how much cooperation happens, and how durable that cooperation is, but it nonetheless is clear is that states at least cooperate when they believe it to be in their clear interests to do so. In the

\footnotetext{
${ }^{36}$ R O Keohane, After Hegemony: Power and Discord in the World Political Economy, Princeton NJ: Princeton University Press, 1984; H Milner, 'International Theories of Cooperation Among Nations: Strengths and Weaknesses', World Politics 44, no. 3, 1992: 466-496, doi:10.2307/2010546; Judith Goldstein, Legalization and World Politics (MIT Press, 2001); B Koremenos, et al, The Rational Design of International Institutions, Cambridge University Press, 2003; A Hurrell, On Global Order : Power, Values, and the Constitution of International Society: Power, Values, and the Constitution of International Society, OUP Oxford, 2007; K W Abbott et al., International Organizations as Orchestrators, Cambridge University Press, 2015.
} 
context of refugee protection, this argument is most trenchantly made by ${ }^{37}$. In the circumstances where states cannot be persuaded to surrender control of eligibility determination, this proposal is a non-starter. However, we would argue that what states would gain in return for this is much more control over who is ultimately settled in their country than they currently possess. States would be empowered to give their preferences as to which refugees they wish to accept to the system, just as refugees give theirs. The likely reason why some states currently are reluctant to sacrifice control over eligibility determination is that they have no control over which refugees come to their country (and, as a consequence, the outcome of the decentralised matching market is unstable).

Moreover, there is prima facie evidence that the circumstances we examine in this paper are cases where states are willing to sacrifice this power. In the case of refugee resettlement, ${ }^{38}$ refugee status determination is already not always conducted by the states which agree to resettle refugees (for example, the US government resettled 60,000 Bhutanese refugees from Nepal in 2006). A coalition of Western states successfully resettled two and a half million Indochinese refugees between 1975 and 1997. ${ }^{39}$ There are therefore numerous circumstances in which states already surrender refugee status determination and a centralised matching system would merely require formalising this process. In the European case, there is a statutory commitment on the part of the member states of the European Union to harmonise who qualifies for refugee status, the Qualification Directive, which is binding on all members of the EU except Denmark.

Even if states cannot be persuaded to use matching in burden-sharing, an individual state could set up a matching system across its different regions (e.g. British local authorities or German Bundesländer). This would have many of the advantages, without the issue of having to get sovereign states to opt in collectively. For example, British local authorities will have granular information about their particular advantages vis-à-vis other councils (e.g. some councils may have more capacity in child services than care for the elderly, and vice versa) and they should be encouraged to convey this information to refugees. Indeed, a refugee matching system could generate dramatic improvement in the welfare and integration of refugees within

\footnotetext{
${ }^{37}$ A Betts (ed.), Global Migration Governance. Oxford University Press 2011.

${ }^{38}$ Resettlement here refers to 'the organized movement of pre-selected refugees to a destination country in which their settlement is expected to be permanent' J Van Selm, 'Refugee Resettlement', in The Oxford Handbook of Refugee and Forced Migration Studies, ed. E Fiddian-Qasmiyeh et al., Oxford University Press, 2014, http://www.oxfordhandbooks.com/view/10.1093/oxfordhb/9780199652433.001.0001/oxfordhb9780199652433-e-014.

${ }^{39}$ C Robinson, Terms of Refuge: The Indochinese Exodus \& the International Response (Zed Books, 1998).
} 
a given country's national borders and significantly reduce ghettoization and restrictionist arguments about capacity gaps.

If states opt into such a system, rather than determining the status of those refugees that have applied to them specifically, they would submit their ranked preferences to the clearinghouse. One disadvantage of this is that now states have to look at all the refugees in the system, rather than only those who happen to have applied to their respective national bureaucracies. Of course, this may not be particularly burdensome, as the ranking could be done using very straightforward principles (for example, a state could priories refugees that have been waiting longest, or face the immediate threat, or that they are best placed to assist).

Once states have committed to taking a given number of refugees, there is a question of how they prioritise which refugees they wish to receive. There are a variety of principles, which academics and policy-makers could seek to use in trying to determine who will be prioritised, given practical and political limits on how many refugees can be taken in. For example, the United Kingdom has recently stated it wishes to expand the Vulnerable Persons Relocation Scheme, which works to resettle Syrian refugees in the UK. The government has stated that their priorities are determined by greatest need, and an assessment of where the UK can singly make the greatest difference. ${ }^{40}$ On the other hand, the governments of Slovakia, Poland, and the Czech Republic have all signalled a willingness to take more refugees, but only if they are Christian. ${ }^{41}$ Many would regard the latter as morally unacceptable and discriminatory, but the former as largely uncontroversial. The point is just, for the moment, that different states are free to rank these principles differently in the status quo, and reasonable, non-reprehensible states might rank the same refugees differently (for example, it would be eminently reasonable for Brazil and France to prefer Lusophone and Francophone refugees respectively). ${ }^{42}$

Using a matching system does not dictate which principles states are allowed to use in ranking refugees, and the clearinghouse could permit or forbid the use of any criteria. Just as matching for doctors does not allow hospitals to engage in racist hiring practices, the clearinghouse would only allow states to rank refugees based on criteria which are compatible with the principles and goals of the 1951 Convention, or any other set of principles (e.g.

\footnotetext{
${ }^{40} \mathrm{~J}$ McDermott and J Vasagar, 'Britain to Take 20,000 Syrian Refugees — but Not from Europe', Financial Times, 7 September 2015, http://www.ft.com/cms/s/0/d709bb32-5581-11e5-9846de406ccb37f2.html\#axzz3mBzPhmK5.

${ }^{41}$ Z Wasik and H Foy, 'Poland Favours Christian Refugees from Syria', Financial Times, 21 August 2015, http://www.ft.com/cms/s/0/6edfdd30-472a-11e5-b3b2-1672f710807b.html\#axzz3mBzPhmK5.

${ }^{42}$ Note that countries can also, in principle, agree on what refugees have the highest priority.
} 
international human rights law). Even if all states ended up ranking refugees in the same way (which is unlikely), the clearinghouse would still be an improvement on the status quo, as it would give refugees themselves more control over their lives.

The Refugee Match is simply the tool which finds the best allocation, given whichever set of principles are embedded in the processes. Irrespective of those principles, what will be true of any matching system is that it will expand the agency of refugees, by giving them greater choice over where they are ultimately protected, without necessitating dangerous and uncertain journeys, and will gives states greater control over which refugees they take in. Right now, the problem is that refugees have no choices, and states have no control. The Refugee Match can help both.

\section{A MANY-TO-ONE MATCH FOR REFUGEES: HOW}

What will the matching system for refugees practically look like? The first step is to agree what the two sides of the system are (i.e. which refugees, and which states). Any subset of states could agree to set up a matching system, and allocate any group of forced migrants. Matching is not about who is to be resettled: it is a system which can be used after a commitment has been made by a given set of states to protect a given set of refugees. For example, it has been suggested that the EU should collectively undertake to relocate 160,000 refugees from Greece, Italy, and Hungary in order to alleviate the chronic strain on those nations' resources. ${ }^{43}$ Matching is not a tool for selecting which refugees should be included in that number, it is a tool for decided who goes where after that decision has been made.

If, as we suggest here, the system is for asylum seekers, the second step is to create a centralised body that will determine the status of applications by individuals to the system. If the individuals are already refugees under the 1951 Convention, or for any other reason are deemed eligible for the system in question, then that is unnecessary. In the European context, there has been much progress towards achieving 'joint processing' of applications according to a standardised set of procedures. ${ }^{44}$ In order to create a system, which ensures that families, which do not wish to be separated, are not, the clearinghouse needs to accept preference

\footnotetext{
${ }^{43}$ J Kanter, 'EU Nations Urged to Accept 160,00 Migrants', New York Times, 9 September 2015.

${ }^{44} \mathrm{H}$ Urth et al., 'Study on the Feasibility and Legal and Practical Implications of Establishing a Mechanism for the Joint Processing of Asylum Applications on the Territory of the EU', European Commission, 2013.
} 
submissions from households. The households would be treated as a single unit, ${ }^{45}$ and states would then evaluate those households in the same way. ${ }^{46}$ One important consideration is whether to take into account interdependent preferences of extended families. For example, parents $\mathrm{A}$ and $\mathrm{B}$ together with their only child $\mathrm{C}$ should be treated as an independent household as should parent D with his children $\mathrm{E}$ and $\mathrm{F}$. But what if B and D are cousins? A-B-C may have different preferences from D-E-F, but other things being equal, they would prefer to be resettled in the same country. This could undermine stability, efficiency, and strategyproofness. This issue has arisen in matching couples in the doctor-hospital match. ${ }^{47}$ Theoretically, these sorts of preferences can create problems for the matching mechanism, but, in practice, ${ }^{48}$ when the number of people participating in the matching system is sufficiently large (and any meaningful system for refugees certainly would be), the system has often functioned very well. In the medical match, doctors who were couple had their preferences satisfactorily met, as could be the case for refugee families.

The next step is to determine the frequency at which the system is cleared (i.e. how often the matching is performed). For example, the NRMP happens annually, whereas the matches formed after speed-dating events happen every day. Designers of the match can adjust the frequency of clearing depending on the urgency and scale of the refugee flows. There is a trade-off here. Less frequent clearing 'thickens' the system, removing incentives to cheat the system, and offering more choice (if there is a larger, and therefore more diverse set of participants on both sides, it is more likely particularly fitting matches will be made). However, it increases the amount refugees spend in potentially vulnerable situations.

Next, states need to determine in practical terms how they are going to rank the refugees that are in the system. Broadly speaking, they have two options: strict or weak ranking. Strict ranking, as in the NRMP, would require the states to assign a position to every single refugee they were willing to consider offering protection to. Realistically, given the numbers of

\footnotetext{
${ }^{45}$ Which means participating states would need to adopt a common understanding of the family unit in question. Currently the definitions of family and dependent-relative status are specific to the jurisdictions of particular states, but this is no more than committed to in many domains of EU law, where a common definition of the family is required.

${ }^{46}$ Families are not 'unsplittable' once their refugee status has been determined for a variety of reasons (for example, one member of the family can commit a crime incompatible with their refugee status without undermining the refugee status of the rest of the family), but this doesn't not undermine the stability of the system, as it does not create scenarios where states and refugees wish to re-match outside the system.

${ }^{47} \mathrm{~A}$ E Roth and E Peranson, 'The Redesign of the Matching Market for American Physicians: Some Engineering Aspects of Economic D', American Economic Review 89, no. 4, 1999: 748-782.

${ }^{48}$ And, as it turns out, even in theory for large markets, see F Kojima, P A Pathak, and A E Roth, 'Matching with Couples: Stability and Incentives in Large Markets*', The Quarterly Journal of Economics 128, no. 4, 2013: 1585-1632, doi:10.1093/qje/qjt019..
} 
refugees and the capacities of state bureaucracies, this is likely to only be achieved by using a points-based system. An alternative is to use weak ranking, as used in the Boston and New York public school system, where the refugees are ranked according to blocs of priority classes. For example, the state could deem those facing immediate personal danger to be the group with the highest priority. Within the classes, whatever they are, the ranking is done according to a lottery (this will only affect the refugees in a country's lowest-ranked priority class that has any but not all members accepted). From the point of view of refugees, the ranking is more straightforward: they simply submit a list of the countries they would be willing to be protected by in rank order (this also works if a given country offers more than one form of protection, such as full refugee status alongside some lesser form of temporary protection. This is explored in more depth below). If one wants to design a system, which guarantees that every refugee is granted protection somewhere, then refugees must rank every single country (otherwise, they are effectively saying that they would rather not be granted protection than go to a particular country).

There is a potential concern about 'manipulability'. Put simply, states may worry that refugees will misrepresent themselves in order to get into higher priority categories (e.g. pretending to have a given educational qualification, or sexuality, if either of those are priority categories). This is a well-known problem, and sometimes leads to individuals making choices to enter into higher priority categories rather than misrepresenting themselves (as when individuals move house to get into a school catchment area to get neighbourhood priority). States must be able to trust the information they are receiving in order for them to consent to opt into such a burden-sharing mechanism at all. Unfortunately, many of the least manipulable priority categories are precisely those categories it would be unacceptable to use (e.g. it is very hard to manipulate one's race or sex). Some important categories are not: for example, some European states have already introduced DNA testing to verify family membership. ${ }^{49}$ There are other categories of priority, which, in certain circumstances, would also be hard to manipulate: for example, who has waited the longest is often a matter of record. Assessing which refugees are in the most immediate danger could be similarly hard to manipulate if, for example, states wished to prioritise those who are registered in settlements immediately on the Turkish-Syrian border in the European case. Most obviously, prioritising children creates a relatively difficult status to manipulate, although it also means that the longer implementation

\footnotetext{
${ }^{49}$ UNHCR, 'UNHCR Note on DNA Testing to Establish Family Relationships in the Refugee Context', 2008, http://www.refworld.org/docid/48620c2d2.html.
} 
of this system is delayed, the more people will be manipulated out of this category by growing up. Finally, the fewer priority classes there are, the easier it would to verify applications and discourage manipulation.

Ultimately, this creates trade-offs, one between which priorities we pick, and one concerning how transparent those priorities are. Refugees are less likely to manipulate the system if they are uncertain about what the priorities of states are. Of course, this raises significant concerns about the transparency and accountability of the system. It would be for the creators of the Refugee Match to assess the relative importance of these goals. They could decide to create a fully transparent system (where the public and refugees know the priority categories and the ranking of priority classes in full), a semi-transparent system (where refugees know that all the categories on their application are being used, but not the ranking of priority classes), and a completely non-transparent system (where refugees neither know the priority ranking of priority classes, nor even which categories are being used). The first category is the most manipulable, and the last category is the least manipulable.

One of the key elements of the matching system for refugees is the determination of quotas. States can have both minimum and maximum quotas if they desire. ${ }^{50}$ The minimum quotas would need to be coordinated between the different states in order to ensure that a sufficient number of refugees are being allocated. In order to ensure that all refugees are allocated, it is important that no state ranks any refugee in the system as unacceptable, and that the minimum quotas of all participating states collectively add up to the total number of refugees. If this can be agreed, it is guaranteed that every refugee in the system will be offered protection somewhere, but if it not, then the refugees given the lowest priority by states would have to wait until those quotas are increased, and the system can clear again. States can unilaterally determine maximum quotas without affecting the functioning of the system. Matching systems with maximum quotas are very well understood and are implemented in a variety of contexts, including the NRMP. Minimum quotas, however, present a challenge to designers of matching systems. ${ }^{51}$ In particular, it is difficult to ensure that the system is stable, efficient, and incentive-compatible. Economists have developed a variety of tools to overcome

\footnotetext{
${ }^{50}$ States can also have subnational quotas in the same way as hospitals fill vacancies for different departments. For example, the German Königsteiner Schlüssel system allocates refugees to Bundesländer based on a system of fixed quotas (for example, Berlin has five per cent of the quota) without any regard for the preferences of refugees themselves.

${ }_{51}^{5}$ L Ehlers, I E Hafalir, M B Yenmez, and M A Yildirim. 'School Choice with Controlled Choice Constraints: Hard Bounds versus Soft Bounds'. Journal of Economic Theory 153, 2014: 648-683.
} 
these difficulties and satisfy these three requirements to some extent in certain settings. For example, Kamada and Kojima develop a matching system for doctors in Japan that ensures that rural hospitals have a minimum complement of medical staff. ${ }^{52}$

Economists have also very recently developed tools to handle 'distributional constraints'. ${ }^{53}$ One setting where this is often used is college admissions systems where affirmative action is a requirement. ${ }^{54}$ Rather than just having minimum quotas, this system also insists that a certain distribution of students from particular backgrounds, ethnic identities, etc. are distributed in every college. In the context of refugees, there may be some reason why states would wish to decide in advance that the refugee populations they take must meet some distributional requirements. States could collectively pre-commit to taking a diverse population of refugees if, for example, one wished to prevent the scenario where some governments take in only Christian refugees. If this is something states wish to do or can be persuaded to accept, this feature can be built into the system.

Another factor which distinguishes this system from most applications of matching models is that it might be reasonably expected that some states would prefer not to be chosen. In such circumstances, countries could deliberately try and make themselves as unwelcoming to refugees as possible, in order to encourage refugees to try to avoid them. In the simplest version of the system, states could pretend to be generous by offering places, then act to guarantee that those places would be unfilled, and a state could thereby shirk their responsibilities to resettle with no penalty. This could result in some states taking disproportionate burdens, leading to collective action breaking down, and the collapse of the system.

This problem can be addressed in a variety of ways. Firstly, minimum quotas offer a partial mitigation of this problem (particular if the minimum quotas are also maximum quotas which collectively sum to the total number of refugees to be resettled) as such a system would guarantee that some refugees were resettled to the least desired countries. If those countries

\footnotetext{
${ }^{52}$ Y Kamada, and F Kojima, 'Stability and Strategy-Proofness for Matching with Constraints: A Problem in the Japanese Medical Match and Its Solution'. The American Economic Review, 2012, 366-370.

${ }^{53}$ Y Kamada and F Kojima, 'Efficient Matching under Distributional Constraints: Theory and Applications', American Economic Review 105, no. 1, 2015: 67-99.

${ }^{54}$ I E Hafalir, M B Yenmez, and M A Yildirim, 'Effective Affirmative Action in School Choice'. Theoretical Economics 8 (2), 2013: 325-363. S D Kominers, and T Sönmez. Forthcoming. 'Designing for Diversity in Matching'. Theoretical Economics.

http://scottkom.com/articles/Kominers_Sonmez_Designing_for_Diversity_in_Matching.pdf.
} 
know that they will be hosting refugees no matter how many others host, their incentives flip: a state which knows it will be welcoming some refugees only has incentives to be as desirable as possible to the refugees it most wishes to host. In fact, the state would have an incentive to invest in welcoming refugees no matter how much they may dislike the idea of hosting refugees in general. This solution gives rise to three key concerns. Firstly, this may be seen as ethically unacceptable, as it would involve forcing refugees to relocate to countries which they had not expressed a preference for. Secondly, it might be thought that this therefore undermines the benefits which accrue from finding apt matches. Thirdly, this may increase the likelihood that refugees will withdraw from one round of matching in the hope of getting one of their preferred matches in a subsequent round, further unravelling the system.

A second solution is proposed by Fernández-Moraga and Rapoport. ${ }^{55}$ In their work, they envisage a centrally imposed sanction mechanism which fines states which end up with unmatched places after refugees are allocated. Further, they point out that a tradeable quota system is a logical way to determine the level (or 'price') of that sanction. Such sanctions would be the stick that would incentivise states to become more attractive, rather than less, to refugees. The key barrier such a solution faces is that it requires a central authority capable of enforcing financial sanctions on states for non-compliance. In contrast to everything else we discuss here, which requires minimal infractions upon sovereignty, this would necessitate that states sacrifice considerable sovereignty to such a body. In the context of the European Union, these powers already exist in theory, although historically their implementation has been patchy, to say the least. There is a long and dishonourable history of states flouting the demands of Brussels when they are seen as too onerous.

Even if this system could be enforced, there are potential consequences which many would regard as undesirable. In practical terms under the proposed initial quota allocation such a system implemented in the present context could lead to some of the poorest countries in the EU paying some of the richest to take their quotas. In one paper, they perform a number of simulations to illustrate the possible workings of their proposed system ${ }^{56}$. For example, in their proposal Hungary receives an initial quota of 1,100 , which it then pays to reduce to 1 . By

\footnotetext{
55 J Fernández-Huertas Moraga and H Rapoport, ‘Tradable Immigration Quotas', Journal of Public Economics 115, July 2014: 94-108, doi:10.1016/j.jpubeco.2014.04.002; 'Tradable Refugee-Admission Quotas and EU Asylum Policy', CESifo Economic Studies 61, no. 3-4, 2015: 638-72, doi:10.1093/cesifo/ifu037; 'Tradable Refugee-Admission Quotas (TRAQs), the Syrian Crisis and the New European Agenda on Migration', IZA Journal of European Labor Studies 4, no. 1, 2015: 23.

${ }^{56}$ Fernández-Huertas Moraga and Rapoport, 'Tradable Refugee-Admission Quotas (TRAQs), the Syrian Crisis and the New European Agenda on Migration'.
} 
contrast, the UK, Ireland, and Denmark all begin on initial quotas of 0 (due to their ability to opt out of European Council decisions taken under Justice and Home Affairs competence), and are paid to raise their admission quotas. Hence, the distributional consequences of such a scheme are in practice dependent on the initial allocation of quotas. Given how unpopular the imposition of such quotas is, trading in practice only partially ameliorates this concern.

The EU quota proposal (used as a benchmark initial allocation by Fernández-Huertas Moraga-Rapoport) also gives Greece and Italy an initial allocation of zero since the EU relocation proposal only deals with a small fraction of the refugees so Greece and Italy would continue to have to host a significant number of current and arriving refugees. Such a system would result in considerable financial reimbursement for such states, if they agree to host more than their initial quota, but if the constraints they face are not easily remedied by finance (e.g. physical limitations on infrastructure and space), or they are otherwise limited from using that money (if, let's just imagine, strictures imposed as part of a bailout prevented them from spending money), this could be of limited use. In Fernández-Huertas Moraga and Rapoport's terms, if there is limited fungibility between 'physical solidarity' (e.g. resettling refugees) and 'financial solidarity' (e.g. paying someone else to do it), then a system of fines and cash transfers will not provide a solution.

Our preferred solution is to require refugees to express preferences over the entire set of countries within the system, combined with minimum quotas which guarantee that each participating country will receive some refugees (and sum to the total number of refugees to be resettled). Such a system would guarantee that every refugee is matched, no spaces are left unfilled, and a state has no incentive to be unattractive. It requires no additional enforcement capacity (of course, states may refuse to participate in a system, but that is much less damaging than states participating then trying to become as unattractive as possible). Such a system faces two obstacles. Firstly, some refugees may still get matched to countries that are extremely low down their list of preferences, even their last, creating strong incentives to move across borders. Secondly, it might be thought that refugees lack the information to express meaningful preferences over such a large set of countries. The first problem can only be mitigated, not fully overcome. It is less of a problem to the extent that both refugees and states have heterogeneous preferences. For example, even if a particular country is undesirable for most, that is fine if it is desirable for even a small subset of refugees (say, those with the skills to fill their particular labour shortages). Indeed, it might be hoped that over the long term, such a system would give incentives to both refugees seeking resettlement and receiving states to engage in further such 
specialisation. More generally, there is some evidence from other contexts in which matching systems have been implemented that this is less of a problem than is commonly assumed. In the context of public school choice, the default assumption of many is that parents largely agree on what the good and bad schools are (i.e. they have almost perfectly correlated preferences). However, this concern turns out to be unfounded. In the context of the Boston school match, Dur et al. (2013) find that between forty-three and sixty-six per cent of students were allocated to the first choice school and none of the students were allocated to their bottom three choices. In grade six, over eighty per cent of students get one of their first two choices and all students were allocated to their top five choice school. ${ }^{57}$ Public school choice is different from refugee resettlement, not least because there are enough public school places in Boston for every child. But the point about incorrectly assuming homogeneity of preferences still applies in our case. Concerns about informational gaps on the part of refugees could be overcome either by providing better information to refugees prior to their expressing preferences (there is already a window between being selected for resettlement and being moved which could be used for this purpose), or through systems which 'impute' preferences by asking refugees to express preferences over the properties of areas they prioritise in resettlement, and using that information to construct a ranking of countries. ${ }^{58}$

The penultimate decision that needs to be made is about precisely which matching mechanism to use. One interesting result from the economics literature ${ }^{59}$ is that there exists no matching mechanism that produces outcomes that are stable, efficient, and at the same time give all agents an incentive to truthfully report their preferences. ${ }^{60}$ Therefore, a choice needs to be made as to which of these properties are most important or to partially relax some of the constraints on what the system must guarantee. ${ }^{61}$

\footnotetext{
${ }^{57}$ Dur et al., 'The Demise of Walk Zones in Boston: Priorities vs. Precedence in School Choice', Working Paper, 2013.

${ }^{58}$ We discuss this possibility in considerably more depth in a forthcoming paper., availale from the authors on request.

59 A E Roth, 'The Economics of Matching: Stability and Incentives'. Mathematics of Operations Research 7 (4): 617-628, 1982.

${ }^{60}$ It is actually much worse than that. For any quotas, it is possible for some preferences that the doctor-proposing Gale-Shapley algorithm results in the doctors getting either their worst or second-worst choice. See K Onur, 'School Choice with Consent', The Quarterly Journal of Economics 125, no. 3, 2010: 1297-1348..

${ }^{61}$ One particularly promising direction has been to consider systems with a large number of participants where these properties are only approximately satisfied (for example, E M Azevedo and E B Budish, 'Strategy-Proofness in the Large', Chicago Booth Research Paper, no. 13, 2013, http://papers.ssrn.com/sol3/papers.cfm?abstract_id=2237425. This paper shows how a weaker version of strategyproofness can square this impossibility circle in large markets).
} 
Finally, the clearinghouse has to be created and supervised. Creating the clearinghouse is a technical challenge analogous to the creation of other international market-based systems such as the EU Emissions Trading System. Once these decisions have been taken, and the clearinghouse created, the actual running of the clearinghouse can be left to technocrats.

\section{STABILITY, EFFICIENCY, AND FAIRNESS IN RESETTLEMENT}

Let us put the concepts of stability, efficiency and strategy-proofness in the context of refugee protection. Stability in our context reflects a sort of 'fairness': no refugees' priority for residence in a particular country will be violated (i.e. no refugee is assigned to a country when there is another refugee somewhere else who is higher up that country's priority list, and wishes to go there). As in public school choice, states (collectively or individually) establish an order of priorities, rather directly ranking refugees. In effect, states do not make active choices about specific individuals, instead pre-committing themselves to a particular way of ranking refugees.

Efficiency is straightforward. Since a country simply assigns priorities to refugees according to an international agreement, we do not need to consider the interests of states in the efficiency calculation (country residence permits are simply objects to be assigned). Hence, assigning some refugee to a more preferred country (without hurting other refugees) may be more efficient even if it violates a country's priorities. It may, however, be considered 'unfair' for receiving states because these refugees may have a lower priority for them than some other group of refugees. This is also the efficiency criterion (i.e. one which only considers efficiency from the point of view of one side of the system) used in public school choice.

A system, which is strategy-proof for refugees, would ensure that no refugee had any reason to misrepresent their genuine preferences over what countries they wished to live in. There would no longer be any reason for a refugee to gamble seeking protection in one country based on an inaccurate belief that they would be more likely to receive protection there, thereby forgoing protection in another country. On the other hand, if the system were designed in order to make it strategy-proof for states, no state would have any incentive to dishonestly misrepresent their position vis-à-vis the refugees they were willing to accept. ${ }^{62}$

\footnotetext{
${ }^{62}$ Indeed, there are also mechanisms that, under certain conditions, can even make it safe for the states to reveal their true quotas. These certain conditions, however, are extremely unlikely to obtain, and are therefore too strong for our purposes. In a matching system with a large number of countries and refugees, neither side would have any incentive to misreport their preferences. See N Immorlica and M Mahdian, 'Marriage, Honesty, and Stability',
} 
It would be for the creators of this system to decide which of these properties to prioritise and what distributional constraints to impose - these desiderata will determine precisely what mechanism should be used (see, for example, Echenique and Yenmez ${ }^{63}$ ). Efficiency seems like an obvious first-order priority. In addition, it may be necessary to ensure the system is strategy-proof for refugees, making it impossible for refugees to game the system, in order to achieve political buy-in. On the other hand, states may care more about creating a system in which it is safe for them to accurately report their preferences, and they can trust that other states are doing the same, thus requiring strategy-proofness for states.

If states do not actively rank refugees, but rather assign priorities to groups of refugees, then the role of stability as 'fairness' is important in order to ensure that the system is transparent and does not arbitrarily discriminate against groups that the state has publicly committed to prioritising.

If states actively rank refugees, then there is a good case for sacrificing stability so that the system can be more efficient and strategy-proof. Preventing re-matching in many settings, such as the doctor-hospital match, or the public school match, is extremely difficult: individuals frequently go outside the system to try and renegotiate their deals under the table, leading to the unravelling of the whole system. This is why stability is normally considered important. ${ }^{64}$ However, in our case, it is unlikely that a refugee will be matched to a country, receive refugee status, and then go on to apply for asylum in another country. This is particularly unlikely if states collectively agree that all such applications must now go through the central mechanism. For example, in Europe, while refugees in the Schengen states may travel to other Schengen states, they may not stay for longer than 90 or work without a permit. Moreover, they need a visa to travel to non-Schengen states. ${ }^{65}$ Therefore, sacrificing stability does not affect the robustness of the outcome of the matching system because most 're-matchings' that would

\footnotetext{
in Proceedings of the Sixteenth Annual ACM-SIAM Symposium on Discrete Algorithms, SODA '05 (Philadelphia, PA, USA: Society for Industrial and Applied Mathematics, 2005), 53-62, http://dl.acm.org/citation.cfm?id=1070432.1070441; Fuhito Kojima and Parag A. Pathak, 'Incentives and Stability in Large Two-Sided Matching Markets', The American Economic Review 99, no. 3 (1 June 2009): 60827.. But there is no guarantee that there will be enough countries participating in any given matching system to ensure this.

${ }^{63}$ F Echenique and M B Yenmez, 'How to Control Controlled School Choice', American Economic Review 105, no. 8, 2015.

${ }^{64}$ A E Roth, 'A Natural Experiment in the Organization of Entry-Level Labour Markets'.

${ }^{65}$ UNHCR, 'Many Refugees Misunderstand Schengen Expansion', 21 December 2007,

http://www.unhcr.org/476bb7e24.html.
} 
render an outcome unstable are prohibited, costly or time-intensive. In a well-designed matching system for refugees, stability comes for free.

\section{A GLOBAL RESETTLEMENT MECHANISM}

In mid-2016, UNHCR estimated that 2017's global resettlement needs will be over 1,190,000 persons. ${ }^{66}$ However, only some 85,000 places are available on an annual basis. ${ }^{67}$ Clearly, the key problem here is that there are nowhere near enough places. Our proposal does not purport to solve that problem. The scarcity of places in resettlement schemes, however, makes it particularly crucial that those places are allocated in the best way possible. As many have argued, international emergencies and crises, such as the current Syrian situation, have unjustly distracted attention from the plight of those in 'protracted refugee situations' (i.e. five years or more), where resettlement places are extremely limited. ${ }^{68}$ In particular, Milner and Loescher recommend 'more effective and strategic use of resettlement as a tool of burden and responsibility sharing, including through the application of a group resettlement referral methodology.' In this context, matching can make resettlement a more effective durable solution, and increase the likelihood that the limited places at our disposal are used well.

In some cases, resettlement functions according to criteria set by UNHCR and tries to encompass priority needs. When resettlement works well, UNHCR acquires much information about refugees through interviews and background checks. Generally speaking, a refugee will be referred to one resettlement country after UNHCR has inferred the refugee's preferences using interviews and so on. This is a system where UNHCR manually processes this information, and ultimately makes the decision for the refugee. As such, matching can be distinguished in two ways. Firstly, even if UNHCR wished to continue with a system where they inferred the preferences of refugees, it would remain possible to automate the actual matching, which would have several advantages we list below. In identifying one country for resettlement, UNHCR are effectively inferring the refugee's 'top' choice alone. If UNHCR could infer a preference list across participating countries, an automated matching system could still indicate a more desirable allocation within their limited resources. Secondly, this bespoke

\footnotetext{
${ }^{66}$ UNHCR, 'UNHCR Projected Global Resettlement Needs' (22nd Annual Tripartite Consultation on Resettlement, Geneva, 2016), http://www.unhcr.org/protection/resettlement/575836267/unhcr-projected-globalresettlement-needs-2017.html.

${ }^{67}$ Van Selm, 'Refugee Resettlement'.

${ }^{68}$ J Milner and G Loescher, 'Responding to Protracted Refugee Situations: Lessons from a Decade of Discussion', Forced Migration Policy Briefing, Oxford, UK: Refugee Studies Centre, 2011.
} 
inferring of preferences through interviews is extremely time- and resource-consuming, and could be substituted for simply asking the refugees themselves what countries, out of the participating states, they would most wish to resettle to. What does not happen currently is that after it has been determined that a refugee will be resettled, they themselves are given agency as to where they go.

In the worst cases, given the limited number of places beyond confirmation of refugee status and the determination of need, states are more or less unconstrained to cherry-pick the refugees they deem most desirable. Often, it will happen that refugees with particular skills or that better meet amorphous 'integration criteria' get resettled first. On the other hand, resettlement for states arise in the context of emergencies where they are presented with a binary choice between taking on an entire group tout court themselves or nothing. For example, European governments panicked in the face of large flows out of Libya following the civil war there and, in the end, resettlement was negligible. ${ }^{69}$

In this context, we propose that the Refugee Match can help with the following problems:

First and most obviously, it can give refugees more choice than they currently possess about where they are resettled rather than being directed by the internal procedures of bureaucracies. Vulnerable refugees could state their preferences as to which of the twenty-odd states operating resettlement schemes they most prefer. We think it likely that refugees themselves have better information about their lives, aspirations and the quality of life they would have in a particular country than an overstretched bureaucracy trying to process this information manually.

Second, a matching system can make the process less arbitrary and contingent on adhoc bilateral deals. In the status quo, states identify particular populations, which come to their attention for a variety of reasons, and simply resettle large numbers from those areas or categories (e.g. women at risk, or lacking safety in situ). Whether a refugee population becomes resettled thus is frequently more to do with the competence and drive of particular civil servants than either a sober assessment of who the vulnerable or the core interests of the state. If states are determined to form particular bilateral relationships, they can continue to do so alongside

\footnotetext{
${ }^{69} \mathrm{~K}$ Koser, Responding to Migration from Complex Humanitarian Emergencies: Lessons Learned from Libya, 23 September 2015, http://lastradainternational.org/lsidocs/Migration\%20lessons\%20learned\%20from\%20Libya.pdf.
} 
the matching system. American resettlement of Iraqis that worked with the US Army during the occupation of Iraq might fit this case. However, under a matching system, states can continuously adjust their quotas, assess priority using universal standards of vulnerability, and let the algorithm do the hard work.

Third, because the computer algorithm finds the matching outcome as soon as the preferences of both sides are submitted, the matching system can speed up resettlement. Refugees in extremely vulnerable situations often wait for years on referral lists. Much of what makes that process slow (such as vulnerability determination and the limited number of places) cannot be ameliorated by matching but it can short-circuit the oft-torturous process of negotiation between UNHCR, IOM and state bureaucracies.

Fourth, because matching enables states to effectively share burdens whilst also empowering them to receive refugees they prefer, this mechanism may encourage further states to participate in resettlement. If states realise that they are not under an obligation or expectation to resettle single-handedly an entire population of refugees, they may have more incentive to join the matching system. In addition, states may find it more palatable to settle a diverse set of smaller refugee groups than a larger and more homogeneous one.

\section{THE EUROPEAN REFUGEE CRISIS}

The substantial inflows of refugees into Europe have dramatically exposed the inadequacy of existing arrangements. The disintegration of Syria, where no less than nine million Syrians have been displaced, of whom three million are refugees, shows no sign of being resolved swiftly. ${ }^{70}$ The overwhelming majority of refugees are in neighbouring countries: Jordan, Lebanon, and Turkey. There are now over a million refugees in Lebanon, in a total population of four million (ibid.). Jordan and Lebanon have closed their borders. Even for those that have reached refugee camps in the region, the situation continues to worsen. Left without the right to work, access to security, basic legal protections, and facing ongoing racism and violence, it is unsurprising that many refugees continue to attempt the long and dangerous journey to Europe. We should assume this situation will be enduring and that refugee flows will continue.

\footnotetext{
${ }^{70}$ UNHCR, 'Syrian Refugees Inter-Agency Regional Update', 20 September 2015, $\mathrm{http}$ //data.unhcr.org/syrianrefugees/regional.php.
} 
Prior to the emergence of this crisis, the European Commission was already considering joint processing, relocation, long-term residence, protected entry procedures and resettlement. ${ }^{71}$ These reports amass a body of policy knowledge and ideas as to how resettlement and relocation can be implemented. What do they do not consider is the possibility of using matching to determine which refugees go to which participating states within the schemes they outline.

The current system, where the first arrival country has responsibility for refugees, is fundamentally unfair to countries such as Greece, Italy, or Hungary, and creates chaos and tragedy as European states play pass-the-parcel with human lives. It has never been clearer that a new deal on responsibility-sharing within Europe is needed to replace the Dublin III Regulation. History suggests interstate cooperation to meet such a challenge is not impossible: from the Comprehensive Action Plan for Indochinese Refugees in 1989 to the European Evacuation of Kosovar refugees from Macedonia in 1999, a clear plan and astute political leadership have led to negotiated cooperation in the past. Crucially, a workable solution requires cooperation across the EU. It is the hope of many that sufficient popular pressure of the sort that followed the publication of the tragic photographs of Aylan Kurdi, may be enough to get states on board, but there is no conflict between that and trying to persuade governments that a coordinated, managed response, is not only better for refugees, but ultimately for states as well.

Given the widespread recognition of the urgency of forming a comprehensive European asylum policy, the crucial role matching can play is in providing states with a framework which might persuade them to participate in burden-sharing arrangements to meet the crisis, thus overcoming the current deadlock.

A matching system can run either alongside or instead of a system modelled on Dublin III, where a refugee applies for protection in one and only one country. This, for example, could replace the current situation where Syrian refugees in the countries bordering Syria may apply for humanitarian visas from particular countries, but must pick a particular country to apply to.

\footnotetext{
${ }^{71}$ J Van Selm et al., 'Study on The Feasibility of Setting up Resettlement Schemes in EU Member States or at EU Level, against the Background of the Common European Asylum System and the Goal of a Common Asylum Procedure', European Commission, 2003; J Van Selm, N Lassen, and J Doomernik, 'Study on The Transfer of Protection Status in the EU, against the Background of the Common European Asylum System and the Goal of a Uniform Status, Valid throughout the Union, for Those Granted Asylum', DG.JAI/A2/2003/001, European Commission, 2004; European Commission, Directorate-General Home Affairs, 'Study on the Feasibility of Establishing a Mechanism for the Relocation of Beneficiaries of International Protection', European Commission, 2010.
} 
Refugees are then tied to a particular application to a particular country (embassies invariably keep the original documentation refugees provide, in part to prevent multiple applications). It advantages nobody that at present refugees must play the lottery in deciding where to apply to, and states cannot evaluate from the entire pool of applicants. Allowing any refugee to apply to a single system from any embassy is therefore in the interests of refugees and states.

Another potential use would be with something analogous to the mass relocation of Kosovans across Europe in the late '90s and early 2000s. ${ }^{72}$ In this case, almost no attempt was made to match refugees and hosting locations. Refugees were sometimes unaware of which country they plane they boarded was taking them to. A matching system could have been used to allocate refugees within that system quickly to a country where they were most-likely to flourish for the duration of their stay without affecting the rest of European refugee regime. In particular, the proposed system could exclude discriminatory categories such as religion and race, which are incompatible with European law, as well as being morally unacceptable, and focus on categories of vulnerability, suitability for integration, presence of family, and so on. The system would then match refugees and states. This, as before, necessitates that eligibility is centrally agreed upon. Yet this is no more than what is already aspired to in the 2011 Qualification Directive. What is currently lacking is a way to persuade states to implement this in practice. But we argue that using matching has further advantages over and above simply persuading states to participate.

Most simply, matching may save lives. The matching system allows refugees to submit an application for asylum to every participating state, and they could, in principle, submit it remotely. It could include, for example, regional processing centres in the Middle East and North Africa. The core advantage is that, to the extent refugees can have confidence that there is a fair and effective system that will grant them protection without attempting a dangerous crossing, they are less likely to take that risk. Unlike naval security operations in the Mediterranean, such as Operation Triton - which merely empower human traffickers and make the journey more dangerous rather than deal with the underlying demand - this is a system which makes refugees outside Europe no less likely to secure protection than those that have reached it (or at least one with a credible and safe alternative to smugglers). Of course, creating a system designed to prevent deaths at sea and provide people with an alternative to dangerous

\footnotetext{
${ }^{72}$ K Kerber, 'The Temporary Protection Directive', European Journal of Migration and Law 4, no. 2, 2002 : 193-214.
} 
crossings is principally and practically separate from the question of dealing with refugees that have already made it to Europe - these refugees must be addressed separately. ${ }^{73}$

Europe also offers a case study of how rapid matching may help manage a sudden chaotic influx. A matching system can be deployed as soon as the states agree on the quotas and the criteria for ranking refugees. To the extent that matching is successful, it reduces the chaos and volatility of rapid population movements as fewer people try and reach (or move across) Europe, because getting to a particular destination has become substantially less important. Furthermore, the unmanaged chaos under the status quo does not make it likely that refugees will end up in the countries they genuinely wish to go to because they have family there, speak a relevant language, have contacts which might help them secure employment, and so on. This is all in the interests of states, because first, states wish to minimise the anarchy of sudden population flows, with the concomitant stress on infrastructure and scarce resources, and second, because it guarantees that they will also end up protecting those refugees they most prefer.

Notably, even if not all states can be persuaded to participate, it still makes sense for those states that are willing to use the matching system to do so. ${ }^{74}$ Hopefully, it should become clear in time to any states staying out of the matching system that they thereby receive less-preferred refugees in comparison to states which do participate, thus encouraging wider participation. For this reason, the refugee match is precisely what can persuade states to opt into refugee burden-sharing, surrender control of eligibility determination, and ultimately protect more refugees.

\section{FURTHER CONSIDERATIONS}

It might be thought this system does not offer genuine choice to refugees, but merely creates a system in which states have all the power, and refugees have none. We argue the opposite. We note that it is states, in the current system, which have virtually all of the power. They may be

\footnotetext{
${ }^{73}$ Right-wing politicians often invoke a distinction between deserving refugees 'there' in order to justify restrictive policies attacking the rights of alleged queue-jumpers 'over here'. It is plausible that we undermine this discourse to the extent that we make it (even more) flagrantly untrue.

${ }^{74}$ Designing mechanisms that encourage agents to participate in it rather than contracting and transacting outside it is an active area of research in matching theory. The bottom line is that it may hard to create bullet-proof incentives for participation in many mechanisms especially if there is uncertainty about the outcome (see, for example, B N Roth and R I Shorrer, 'A Model of Mechanism Design in the Presence of a Pre-Existing Game', Mimeo, February 2015, http://scholar.harvard.edu/files/ran/files/mediators_0.pdf?m=1426648159.).
} 
constrained by international norms or legal obligations, but only weakly at best. Yet neither side has any choice. States must process only those who apply within their borders, refugees must accept the protection or resettlement that is offered to them, even where there is a country that they would have preferred to go to, that also would have preferred to take them. A matching system is exactly the situation where both sides need to agree. Refugees already exist within an international system of states, where it is necessary for a state to agree to render protection in order for a refugee to receive it. Pace total global open borders, the assent of states is a precondition for protection, and only agreement from both sides gives refugees any choices at all. Currently, much activism works assumes a strict dichotomy, where refugees can either have unconstrained choice, or not choice at all. For example, some European refugee activists advocate a system which would give refugees to the EU total freedom as to where in the EU they decided to live while states are compensated for every refugee they take. ${ }^{75}$ This would be the best outcome for all refugees, but there is little-to-no chance states would assent to it. But this dichotomy also misses that in most scenarios justice does not require that we give individuals total choice, but choice from a reasonable set of options. Few would advocate that students must have the right to go to any university they wish, or doctors to work at any hospital. What is important is that they go to good universities and hospitals, and if both sides of the system have some choice, that is more likely to happen. Those choices, although not complete, are nonetheless real. If it really is the case that almost every Syrian refugee makes Germany their first preference, then of course they will not all be able to go there, but refugees would still have qualitatively more agency if they were to achieve their second, third, fourth, or fifth preference.

Were every refugee to submit the same preference ranking from beginning to end, states would merely pick the refugees they prefer (rather as if everyone in a given school district agreed completely on the desirability of the schools). Scenarios of "perfect correlation of preferences', such as this, do indeed hand all of the power to the other side of the system (be that states, or schools). But this is extremely unlikely. In the Boston public school matching system, the image of a single hopelessly oversubscribed school is largely mythical, as Dur et al. (2013) point out. There are abundant reasons to believe that the preferences of refugees are as heterogeneous as they themselves are, as are those of countries. This heterogeneity is exactly what makes the matching system so appropriate and powerful.

\footnotetext{
${ }^{75}$ E.g. G Granjon, 'Freedom of Movement under European Conditions', Euractiv, 28 July 2014, http://www.euractiv.com/section/social-europe-jobs/opinion/freedom-of-movement-under-european-conditions/.
} 
Second, it might be thought that neither states nor refugees possess sufficient information for matching to be effective. In the status quo, states compete at telling refugees how unpleasantly they will treat them (as when Geert Wilders released YouTube videos telling refugees they had no chance of ever getting status in the Netherlands, and similar flyer campaigns of the Australian government in camps across Asia). Matching changes the game completely. In a matching system, where it is fixed in advance how many refugees will be matched to a given country, but not which refugees, it is suddenly important for states to compete at being attractive. This no longer affects the total number of refugees they will host (which was determined in advance), but it does affect who they will host. Because the match is two-sided, a state cannot merely take in the refugees it wants, if those refugees would prefer to go somewhere else. Hence, states will have strong incentives to invest in refugee reception and inform the refugees about how welcoming they will be. ${ }^{76}$

Third, it might be thought that a system of this form commodifies refugees, turning them into objects to be traded, exchanged, and competed over by states. Again, the opposite is the case. A two-sided system respects the preferences of agents on both sides. Rather than turning refugees into numbers, or 'human cargo' where refugees are passive recipients of the largesse of states, refugees become agents with preferences, choices, and agendas, and those preferences are now taken into account. A matching system is distinct from a traditional market for a commodity, as it requires consent of both parties, and does not involve money. It is thus no more commodifying than marriage, friendships, or public education.

Fourth, some will undoubtedly think it unacceptable to promote or give any legitimation to a discourse of 'desirable' and 'undesirable' refugees. We have several responses. Merely by centralising matching in a clearinghouse, we establish shared norms about what is acceptable and what is not. It prevents states from unilaterally creating arbitrary policies for political purposes. ${ }^{77}$ Secondly, a system where states must submit these preferences to a centralised system makes them substantially more accountable to public scrutiny and judicial review than a system where states identify and take desirable refugees on the quiet. More importantly, a preference ranking is not an index of desirability, but rather of priority. For example, a

\footnotetext{
${ }^{76}$ By the same token, states might have an incentive to discourage certain refugees from applying because they cannot legally discriminate against them within the priorities defined by the matching system (although odious states that prioritise their Islamophobia over filling their skills gaps will be punished economically in the long term).

${ }^{77}$ Such as when states announce a willingness to cherry-pick telegenic orphans plucked straight from the Syrian border
} 
university admissions system can accord priority rank to those from untraditional backgrounds, or who face additional barriers to attending university. In the same way, a preference ranking of states can reflect an assessment of who faces the greatest need, vulnerability, or any number of other variables to do with a refugee's suitability for a given country that have nothing to do with evaluations of desirability. All that the matching system does is aggregate the priorities of states and refugees, and arrive at the optimal outcome within the constraints. It is undeniable that some states currently behave reprehensibly and others do not. But whether or not they do, both selfish and altruistic preferences would be better satisfied within the Refugee Match.

\section{CONCLUSION}

Of course, in order to actually resolve refugee crises of this form, states would have to accept enormous inflows of refugees, and find a way to resolve the ongoing conflagration in Syria and elsewhere. Matching systems, such as the one we propose here, are never the total solution to the various issues they seek to address. They are merely a substantial improvement on the status quo within the constraints of the politically palatable, and may give states incentives to relax these constraints. Although matching mechanisms cannot make states behave morally, they will nonetheless improve the situation for refugees whether or not states can be made to act in accordance with their legal and moral obligations. Our work, therefore, provides a pragmatic proposal in the spirit of those who argue that states will contribute towards efforts to protect refugees when they recognise a relationship between the rights of refugees and their own interests. $^{78}$

The Refugee Match is a realistic, pragmatic, quickly implementable, and just improvement on much of the current international refugee regime. In this paper, we outlined how a matching system, which respects the preferences and choices of refugees and the priorities of states, can better protect the human rights of the vulnerable, and increase the likelihood that states will participate in burden-sharing.

This also exposes a particularly unhelpful and misleading platitude in the current rhetoric of Europe's politicians. To take one example, in September of 2015, Thomas de Maizière, Interior Minister of Germany, announced the closure of the German border to Syrian

\footnotetext{
${ }^{78}$ E.g. A Betts, Protection by Persuasion: International Cooperation in the Refugee Regime. Cornell University Press, 2009.
} 
refugees. He told a press conference that "asylum seekers must understand that they cannot choose the states where they are seeking protection". 79

Nonsense. Any system which genuinely upheld the rights of refugees would have to start by respecting their choices. Asylum seekers must be able to choose the states where they want to spend their lives. The Refugee Match is a good start.

\footnotetext{
${ }^{79}$ L Harding, 'Refugee Crisis: Germany Reinstates Controls at Austrian Border', The Guardian, 13 September 2015, sec. World news, http://www.theguardian.com/world/2015/sep/13/germany-to-close-borders-exitschengen-emergency-measures?CMP=Share_iOSApp_Other.
} 


\section{Works Cited:}

A Abdulkadiroğlu, Atila, and T Sönmez, 'House Allocation with Existing Tenants'. Journal of Economic Theory 88 (2), 1999: 233-260.

, 'School Choice: A Mechanism Design Approach'. The American Economic Review 93 (3), 2003: 729-747.

A Abdulkadiroğlu, P A Pathak, and A E Roth. 'The New York City High School Match'. American Economic Review 95 (2), 2005: 364-367.

KW Abbott, P Genschel, D Snidal, and B Zangl. International Organizations as Orchestrators. Cambridge University Press, 2015.

C Alfred, 'What History Can Teach Us About The Worst Refugee Crisis Since WWII'. The Huffington Post, September 12, 2015. http:/www.huffingtonpost.com/entry/alexander-betts-refugeeswwii_55f30f7ce4b077ca094edaec.

D Anker, J Fitzpatrick, and A Shacknove. 'Crisis and Cure: A Reply to Hathaway/Neve and Schuck'. Harvard Human Rights Journal 11, 1998: 295.

C Avery, C Jolls, R A Posner, and A E Roth. 'The New Market for Federal Judicial Law Clerks'. The University of Chicago Law Review, 2007, 447-486.

E M Azevedo, and E B Budish. 'Strategy-Proofness in the Large'. Chicago Booth Research Paper, no. 13, 2013. http://papers.ssrn.com/sol3/papers.cfm?abstract_id=2237425.

C Bauloz, M Ineli-Ciger, S Singer, and V Stoyanova, eds. Seeking Asylum in the European Union: Selected Protection Issues Raised by the Second Phase of the Common European Asylum System. Leiden: Brill/Nijhoff, 2015.

A Betts, 'What Does "Efficiency" Mean in the Context of the Global Refugee Regime?' The British Journal of Politics \& International Relations 8, no. 2, 2006: 148-173.

, Protection by Persuasion: International Cooperation in the Refugee Regime. Cornell University Press, 2009.

(ed.), Global Migration Governance. Oxford University Press 2011. , 'Let Refugees Fly to Europe'. New York Times, 24 September 2015, Online Edition edition. http://www.nytimes.com/2015/09/25/opinion/let-refugees-fly-to-europe.html?nytmobile=0.

V Chetail. 'Looking Beyond the Rhetoric of the Refugee Crisis: The Failed Reform of the Common European Asylum System'. European Journal of Human Rights 5, 2016: 584-601.

V Chetail, P De Bruycker, and F Maiani, eds. Reforming the Common Asylum System: The New European Refugee Law. Leiden/Boston: Brill/Nijhoff, 2016.

B S Chimni,. 'The Global Refugee Problem in the 21st Century and the Emerging Seucity Paradigm: A Disturbing Trend'. In Legal Visions of the 21st Century: Essays in Honour of Judge Christopher Weeramantry, edited by A Anghie and G Sturgess. Martinus Nijhoff Publishers, 1998.

C Costello, , and M-G Guiffré. “"Tragedy” and Responsibility in the Mediterranean'. Open Democracy. April 27, 2015. https://www.opendemocracy.net/can-europe-make-it/mariagiuliagiuffr $\%$ C3\%A9-cathryn-costello/crocodile-tears-tragedy-and-responsibility-i;

U Dur, S D Kominers, P A Pathak, and T Sönmez. 'The Demise of Walk Zones in Boston: Priorities vs. Precedence in School Choice'. Working Paper, 2013.

F Echenique, and M B Yenmez. 'How to Control Controlled School Choice'. American Economic Review 105, no. 8, 2015.

L Ehlers, I E Hafalir, M B Yenmez, and M A Yildirim. 'School Choice with Controlled Choice Constraints: Hard Bounds versus Soft Bounds'. Journal of Economic Theory 153, 2014: 648683.

S Erlanger, and A Smale. 'Europe's Halting Response to Migrant Crisis Draws Criticism as Toll Mounts'. The New York Times, August 28, 2015. https://www.nytimes.com/2015/08/29/world/europe/europe-migrant-refugee-crisis.html.

European Commission, Directorate-General Home Affairs. 'Study on the Feasibility of Establishing a Mechanism for the Relocation of Beneficiaries of International Protection'. European Commission, 2010. 
J Fernández-Huertas Moraga, and H Rapoport. 'Tradable Refugee-Admission Quotas and EU Asylum Policy'. CESifo Economic Studies 61, no. 3-4, 2015: 638-72. doi:10.1093/cesifo/ifu037.

, 'Tradable Immigration Quotas'. Journal of Public Economics 115, July 2014: 94-108. doi:10.1016/j.jpubeco.2014.04.002.

, 'Tradable Refugee-Admission Quotas (TRAQs), the Syrian Crisis and the New European Agenda on Migration'. IZA Journal of European Labor Studies 4, no. 1, 2015: 23.

D Gale, and L S Shapley, 'College Admissions and the Stability of Marriage'. American Mathematical Monthly, 9-15, 1962.

M Gibney, and R Hansen. 'Asylum Policy in the West: Past Trends, Future Possibilities'. In Poverty, International Migration and Asylum, edited by G J Borjas and J Crisp. Palgrave Macmillan, 2005.

M Gibney, 'Refugees and Justice between States'. European Journal of Political Theory, 25 May 2015, 1474885115585325. doi:10.1177/1474885115585325.

J Goldstein, Legalization and World Politics. MIT Press, 2001.

G Granjon, 'Freedom of Movement under European Conditions'. Euractiv, 28 July 2014. http:/www.euractiv.com/section/social-europe-jobs/opinion/freedom-of-movement-undereuropean-conditions/.

I E Hafalir, M B Yenmez, and M A Yildirim, 'Effective Affirmative Action in School Choice'. Theoretical Economics 8 (2), 2013: 325-363.

L Harding, 'Refugee Crisis: Germany Reinstates Controls at Austrian Border'. The Guardian, 13 September 2015, sec. World news. http://www.theguardian.com/world/2015/sep/13/germanyto-close-borders-exit-schengen-emergency-measures?CMP=Share_iOSApp_Other.

J C Hathaway, and R A Neve. 'Making International Refugee Law Relevant Again: A Proposal for Collectivized and Solution-Oriented Protection'. Harv. Hum. Rts. J. 10 (1997): 115.

M den Heijer, J Rijpma, and T Spijkerboar. 'Coercion, Prohibition, and Great Expectations: The Continuing Failure of the Common European Asylum System'. Common Market Law Review 53, no. 3, 2016: 607-42.

A Hurrell, On Global Order: Power, Values, and the Constitution of International Society: Power, Values, and the Constitution of International Society. OUP Oxford, 2007.

$\mathrm{N}$ Immorlica, and M Mahdian. 'Marriage, Honesty, and Stability'. In Proceedings of the Sixteenth Annual ACM-SIAM Symposium on Discrete Algorithms, 53-62. SODA '05. Philadelphia, PA, USA: Society for Industrial and Applied Mathematics, 2005. http://dl.acm.org/citation.cfm?id=1070432.1070441.

U I Jensen, 'Humanitarian Visas: Option or Obligation?' Study for the LIBE Committee. DirectorateGeneral for Internal Policies, European Parliament, 2014.

Y Kamada, and F Kojima, 'Stability and Strategy-Proofness for Matching with Constraints: A Problem in the Japanese Medical Match and Its Solution'. The American Economic Review, 2012, 366370 .

,Efficient Matching under Distributional Constraints: Theory and Applications'. American Economic Review 105, no. 1, 2015: 67-99.

J Kanter, 'EU Nations Urged to Accept 160,00 Migrants'. New York Times, 9 September 2015.

R O Keohane, After Hegemony: Power and Discord in the World Political Economy. Princeton NJ: Princeton University Press, 1984.

K Kerber, 'The Temporary Protection Directive'. European Journal of Migration and Law 4, no. 2, 2002: 193-214.

O Kesten, 'School Choice with Consent'. The Quarterly Journal of Economics 125, no. 3, 2010: 12971348.

F Kojima, and P A Pathak. 'Incentives and Stability in Large Two-Sided Matching Markets'. The American Economic Review 99, no. 3, 1 June 2009: 608-27.

F Kojima, P A Pathak, and A E Roth. 'Matching with Couples: Stability and Incentives in Large Markets*'. The Quarterly Journal of Economics 128, no. 4, 1 November 2013: 1585-1632. doi:10.1093/qje/qjt019.

S D Kominers, and T Sönmez. Forthcoming. 'Designing for Diversity in Matching'. Theoretical Economics.

http://scottkom.com/articles/Kominers_Sonmez_Designing_for_Diversity_in_Matching.pdf. 
B Koremenos, C Lipson, and D Snidal. The Rational Design of International Institutions. Cambridge University Press, 2003.

K Koser. Responding to Migration from Complex Humanitarian Emergencies: Lessons Learned from Libya.

2015. http://lastradainternational.org/lsidocs/Migration\%20lessons $\% 20$ learned $\% 20$ from\%20Libya.p df.

'Time to Reform the International Refugee Regime'. OUPblog. 2015. http://blog.oup.com/2015/09/international-refugee-regime-reform/.

J Kuosmanen 'What (If Anything) Is Wrong with Trading Refugee Quotas?' Res Publica 19, no. 2,25 September 2012: 103-19. doi:10.1007/s11158-012-9198-y.

G Loescher, and J A Scanlan, Calculated Kindness. Simon and Schuster, 1998.

J McDermott, and J Vasagar. 'Britain to Take 20,000 Syrian Refugees - but Not from Europe'. Financial Times, 7 September 2015. http://www.ft.com/cms/s/0/d709bb32-5581-11e5-9846de406ccb37f2.html\#axzz3mBzPhmK5.

H Milne. 'International Theories of Cooperation Among Nations: Strengths and Weaknesses'. World Politics 44, no. 3, April 1992: 466-496. doi:10.2307/2010546.

J Milner, and G Loescher. 'Responding to Protracted Refugee Situations: Lessons from a Decade of Discussion'. Forced Migration Policy Briefing. Oxford, UK: Refugee Studies Centre, 2011.

G Parker, and D Robinson. 'Cameron Opposes Change to EU "Dublin" Rule on Hosting of Refugees'. Financial Times. 20 January 2016.

S Peers, 'The Second Phase of the Common European Asylum System - A Brave New World or Lipstick on a Pig?' Statewatch Analysis, 2013.

C Robinson, Terms of Refuge: The Indochinese Exodus \& the International Response. Zed Books, 1998.

A E Roth, 'The Economics of Matching: Stability and Incentives'. Mathematics of Operations Research 7 (4): 617-628, 1982.

'The Evolution of the Labor Market for Medical Interns and Residents: A Case Study in Game Theory'. The Journal of Political Economy, 1984, 991-1016.

, 'On the Allocation of Residents to Rural Hospitals: A General Property of Two-Sided Matching Markets'. Econometrica 54, no. 2, 1986: 425-27.

, 'A Natural Experiment in the Organization of Entry-Level Labor Markets: Regional Markets for New Physicians and Surgeons in the United Kingdom'. The American Economic Review, 1991, 415-440.

, and E Peranson. 'The Redesign of the Matching Market for American Physicians: Some Engineering Aspects of Economic D'. American Economic Review 89, no. 4, 1999: 748-782.

, 'Repugnance as a Constraint on Markets'. The Journal of Economic Perspectives 21 (3): 2, 2007.

, Who Gets What - and Why: The Hidden World of Matchmaking and Market Design. Harper Collins Publ. UK, 2015.

A E Roth, T Sönmez, and M U Unver. 2004. 'Kidney Exchange'. Quarterly Journal of Economics 119 (2), 2004: 457-88.

B N Roth and R I Shorrer. 'A Model of Mechanism Design in the Presence of a Pre-Existing Game'. Mimeo, February

2015. http://scholar.harvard.edu/files/ran/files/mediators_0.pdf?m=1426648159.

P Schuck, 'Refugee Burden-Sharing: A Modest Proposal'. Yale J. Int'l L. 22, 1997: 243.

T Sönmez, and T B Switzer. 'Matching With (Branch-of-Choice) Contracts at the United States Military Academy'. Econometrica 81 (2), 2013: 451-488.

UNHCR. 'Many Refugees Misunderstand Schengen Expansion', 21 December 2007. http://www.unhcr.org/476bb7e24.html.

'Syrian Refugees Inter-Agency Regional Update', 20 September 2015. http://data.unhcr.org/syrianrefugees/regional.php.

, 'UNHCR Note on DNA Testing to Establish Family Relationships in the Refugee Context', 2008. http://www.refworld.org/docid/48620c2d2.html.

, 'UNHCR Projected Global Resettlement Needs'. 22nd Annual Tripartite Consultation on Resettlement, Geneva, 2016. http://www.unhcr.org/protection/resettlement/575836267/unhcrprojected-global-resettlement-needs-2017.html. 
H Urth, M H Bausager, H-M Kuhn, and J Van Selm. 'Study on the Feasibility and Legal and Practical Implications of Establishing a Mechanism for the Joint Processing of Asylum Applications on the Territory of the EU'. European Commission, 2013.

J Van Selm, 'Refugee Resettlement'. In The Oxford Handbook of Refugee and Forced Migration Studies, edited by E Fiddian-Qasmiyeh, G Loescher, K Long, and N Sigona. Oxford University Press, 2014. http://www.oxfordhandbooks.com/view/10.1093/oxfordhb/9780199652433.001.0001/oxfordh b-9780199652433-e-014.

J Van Selm, N Lassen, and J Doomernik. 'Study on The Transfer of Protection Status in the EU, against the Background of the Common European Asylum System and the Goal of a Uniform Status, Valid throughout the Union, for Those Granted Asylum'. DG.JAI/A2/2003/001. European Commission, 2004.

J Van Selm, T Woroby, E Patrick, and M Matts. 'Study on The Feasibility of Setting up Resettlement Schemes in EU Member States or at EU Level, against the Background of the Common European Asylum System and the Goal of a Common Asylum Procedure'. European Commission, 2003.

S Velluti, Reforming the Common European Aslyum System - Legislative Developments and Judicial Activism of the European Courts. Springer, 2014.

Z Wasik, and H Foy. 'Poland Favours Christian Refugees from Syria'. Financial Times, 21 August 2015. 1672f710807b.html\#axzz3mBzPhmK5.

A Westkamp, 'An Analysis of the German University Admissions System'. Economic Theory 53 (3), 2013: 561-589. 